\title{
Increased Sensitivity to Alcohol Induced Changes in ERK Map Kinase Phosphorylation and Memory Disruption in Adolescent as Compared to Adult C57BL/6J Mice
}

\author{
Marina Spanos $^{c}$, Joyce Besheer ${ }^{a, b, c}$, and Clyde W. Hodge ${ }^{a, b, c}$ \\ a Bowles Center for Alcohol Studies, School of Medicine University of North Carolina at Chapel \\ Hill Thurston-Bowles Building; CB \#7178 Chapel Hill, NC 27599 \\ ${ }^{b}$ Department of Psychiatry, School of Medicine University of North Carolina at Chapel Hill \\ Thurston-Bowles Building; CB \#7178 Chapel Hill, NC 27599 \\ c Neurobiology Curriculum, School of Medicine University of North Carolina at Chapel Hill \\ Thurston-Bowles Building; CB \#7178 Chapel Hill, NC 27599
}

\section{Abstract}

Adolescence is a critical period of brain development that is accompanied by increased probability of risky behavior, such as alcohol use. Emerging research indicates that adolescents are differentially sensitive to the behavioral effects of acute ethanol as compared to adults but the neurobiological mechanisms of this effect remain to be fully elucidated. This study was designed to evaluate effects of acute ethanol on extracellular signal-regulated kinase phosphorylation (pERK1/2) in mesocorticolimbic brain regions. We also sought to determine if age-specific effects of ethanol on p-ERK1/2 are associated with ethanol-induced behavioral deficits on acquisition of the hippocampal-dependent novel object recognition (NOR) test. Adolescent and adult C57BL/6J mice were administered acute ethanol ( $00.5,1$, or $3 \mathrm{~g} / \mathrm{kg}$, i.p.). Brains were removed 30-min post injection and processed for analysis of p-ERK1/2 immunoreactivity (IR). Additional groups of mice were administered ethanol ( 0 or $1 \mathrm{~g} / \mathrm{kg}$ ) prior to the NOR test. Analysis of p-ERK1/2 IR showed that untreated adolescent mice had significantly higher levels of p-ERK1/2 IR in the nucleus accumbens shell, basolateral amygdala (BLA), central amygdala (CeA), and medial prefrontal cortex (mPFC) as compared to adults. Ethanol $(1 \mathrm{~g} / \mathrm{kg})$ selectively reduced p-ERK1/2 IR in the dentate gyrus and increased p-ERK1/2 IR in the BLA only in adolescent mice. Ethanol $(3 \mathrm{~g} / \mathrm{kg})$ produced the same effects on p-ERK1/2 IR in both age groups with increases in CeA and mPFC, but a decrease in the dentate gyrus, as compared to age-matched saline controls. Pretreatment with ethanol $(1 \mathrm{~g} / \mathrm{kg})$ disrupted performance on the NOR test specifically in adolescents, which corresponds with the ethanol-induced inhibition of p-ERK1/2 IR in the hippocampus. These data show that adolescent mice have differential expression of basal pERK1/2 IR in mesocorticolimbic brain regions. Acute ethanol produces a unique set of changes in ERK1/2 phosphorylation in the adolescent brain that are associated with disruption of hippocampal-dependent memory acquisition.

(C) 2012 Elsevier B.V. All rights reserved.

Correspondence: Clyde W. Hodge, Ph. D. Bowles Center for Alcohol Studies University of North Carolina at Chapel Hill Thurston Bowles Building; CB \#7178 Chapel Hill, NC 27599 Voice: 919-966-5678 chodge @ med.unc.edu.

Publisher's Disclaimer: This is a PDF file of an unedited manuscript that has been accepted for publication. As a service to our customers we are providing this early version of the manuscript. The manuscript will undergo copyediting, typesetting, and review of the resulting proof before it is published in its final citable form. Please note that during the production process errors may be discovered which could affect the content, and all legal disclaimers that apply to the journal pertain.

Conflict of interest

The authors declare that they have no actual or potential conflict of interest associated with the conduct of this work. 


\section{Keywords}

ERK; MAP Kinase; Ethanol; Alcohol; Acute; Adolescent; Adult; Novel Object Recognition;

Hippocampus; Amygdala

\section{Introduction}

Adolescence is a critical period of developmental during which young mammals undergo behavioral and neurobiological changes that mark the transition to adulthood [1]. During this developmental period individuals exhibit characteristic behaviors including increases in novelty seeking and risk-taking, which may lead to experimentation with drugs of abuse [2-5]. Accordingly, adolescence is the period during which alcohol (ethanol) use in humans is often initiated. Alcohol use and abuse by adolescents is higher than any other drug with $72 \%$ of high school seniors surveyed reporting some alcohol use and over half (55\%) reporting having been drunk [6]. Alcohol use during adolescence is associated with a 3-fold greater risk of future dependence during adulthood as compared with individuals who initiate use later in development [7]. Moreover, altered low response to acute alcohol during adolescence is a potent predictor of development of alcoholism during adulthood [8,9]. Thus, it is a key challenge to the field to address the effects of acute ethanol on brain and behavioral function during this precarious ontogenetic stage [10].

A growing body of preclinical evidence indicates that adolescents and adults are differentially sensitive to behavioral effects of acute ethanol. Some studies have shown that adolescent rodents are less sensitive to ethanol-induced acute withdrawal, intoxication, motor-impairments, and sedation as compared to adults [11-16]. Other studies have shown that adolescent rodents are more sensitive to ethanol-induced locomotor activation, hypothermia, anxiolysis, memory impairment, and social interaction than adult rodents [13, 15, 17-20]. The neurobiological mechanisms that underlie the variety of developmental differences in responses to acute ethanol have not been fully characterized.

The extracellular signal-regulated kinase (ERK) cell signaling pathway is an appealing candidate for study based on its regulation of key neurotransmitter systems, including dopamine and glutamate, which continue to mature during adolescence $[21,22]$ and are altered by repeated ethanol exposure during this developmental stage [23]. The two closely related isoforms of ERK (ERK1 and ERK2, or ERK1/2) are widely expressed in the central nervous system and are involved in cell growth, proliferation, and survival, and have been shown to be modulated by drugs of abuse [24-27]. Specifically, ERK1/2 activation (phosphorylation) is modulated by ethanol in a dose, treatment (acute vs. chronic), and brain region-dependent manner. For instance, acute ethanol administration $(1.5-3.5 \mathrm{~g} / \mathrm{kg})$ produced dose- and time-dependent decreases in ERK1/2 phosphorylation (p-ERK1/2) in the cerebral cortex of mice without effecting total ERK1/2 levels [28]. ERK1/2 phosphorylation increased in the Edinger-Westphal nucleus of mice after a $3 \mathrm{~g} / \mathrm{kg}$ acute ethanol injection [29]. Injection of a high dose of acute ethanol $(3.5 \mathrm{~g} / \mathrm{kg})$ decreased pERK1/2 in the cerebral cortex and hippocampus in rat pups at PND5, PND21 and as adults [30]. Low to moderate doses of ethanol $(0-2 \mathrm{~g} / \mathrm{kg})$ produce dose-dependent increases in $\mathrm{p}$ ERK1/2 immunoreactivity in the nucleus accumbens, bed nucleus of the stria terminalis, and central amygdala [31]. Together, these studies provide evidence that acute ethanol alters pERK1/2 activity in specific mammalian brain regions that may influence numerous critical functions of the organism including learning, memory, emotion, and reward. However, the extent to which acute ethanol-induced effects on ERK1/2 phosphorylation vary as a function of adolescence remains to be addressed. 
ERK1/2 signaling is critical for neural and behavioral plasticity [32], which may be of special importance to the adolescent response to ethanol [33]. Activation of the ERK/MAPK cascade in the hippocampus is critical for memory processes [34-37], and pharmacological blockade of hippocampal ERK1/2 activation with the MEK1/2 inhibitor SL327 impairs performance on several memory tasks [34, 35, 38, 39]. As a sedative-hypnotic compound, ethanol has long been known to produce dose-dependent effects on memory [40, 41] including object recognition memory [42], which is regulated by ERK1/2 signaling [37, 43]. Importantly, the ERK1/2 signaling pathway is downstream of NMDA receptors in the hippocampus and evidence indicates that ethanol more potently attenuates NMDA receptormediated excitatory postsynaptic potentials in adolescent hippocampus [44] and acquisition of hippocampal-dependent spatial memory acquisition in adolescents as compared to adults [17]. To date there has been no examination of the effects of acute ethanol on adolescent ERK1/2 activation and its potential involvement in memory processes.

To address these gaps in knowledge, the present study sought to first characterize ontogenetic and brain regional differences in the ERK/MAPK signaling pathway under basal conditions and following acute ethanol administration in C57BL/6J mice. Adolescent (42 days) and adult mice (84 days) were administered a range of acute ethanol doses $(0,0.5,1,3$ $\mathrm{g} / \mathrm{kg} \mathrm{IP}$ ) and were sacrificed 30 minutes later for evaluation of p-ERK1/2 immunoreactivity (IR) in mesocorticolimbic brain regions including medial prefrontal cortex (mPFC), nucleus accumbens core and shell (NAcbC and NAcBSh), central amygdala (CeA), basolateral amygdala (BLA) and hippocampus. In addition, ontogenetic effects of pretreatment with acute ethanol $(1 \mathrm{~g} / \mathrm{kg})$ were examined on memory acquisition in the hippocampal-dependent novel object recognition test [45-47] using an automated assessment of object exploration $[48,49]$.

\section{Materials and Methods}

\subsection{Animals}

Male C57BL/6J mice (Jackson Laboratories, Bar Harbor, Maine) were housed 4 per cage in standard Plexiglas cages with a small PVC pipe in each cage for environmental enrichment. Food and water were available ad libitum in the home cage. The mice were 21 days (early adolescence) and 63 days (adult) of age upon arrival to the facility. The colony room was maintained at $21 \pm 1{ }^{\circ} \mathrm{C}$ on a 12-hour light/dark cycle (lights on 20:00) with experiments performed during the dark cycle. The mice were handled and weighed for 21 days before experiments began to acclimate to the reverse light cycle, resume normal sleep/wake cycles [50] and allow the mice to reach late adolescence (PND 42) and adulthood (PND 84). Animals were under continuous care and monitoring by the Division of Laboratory Animal Medicine (DLAM) at UNC-Chapel Hill. All procedures were carried out in accordance with the NIH Guide to Care and Use of laboratory Animals (National Research Council, 1996) and institutional guidelines.

\subsection{Acute Ethanol Treatment}

To habituate mice to intraperitoneal injection, all mice were administered saline $(0.1 \mathrm{ml} /$ $10 \mathrm{~g}$ ) once per day for three days prior to the start of the experiment (PND $39-41$ for adolescent and PND $81-83$ for adult mice). Ethanol (95\%w/v) was diluted in physiological saline $(0.9 \%)$ to a concentration of $20 \%(\mathrm{v} / \mathrm{v})$ and administered in various volumes to obtain the appropriate dose. On the day of the experiment, adolescent (PND 42) and adult (PND 84) mice received ethanol $(0,0.5,1$ or $3 \mathrm{~g} / \mathrm{kg}$, IP). A parallel saline control group was run for each group of ethanol treated mice. 


\subsection{Immunohistochemistry}

Thirty minutes after ethanol or vehicle injection, mice were deeply anesthetized with 100 $\mathrm{mg} / \mathrm{kg}$ pentobarbital and then transcardially perfused with $0.1 \mathrm{M}$ phosphate buffered saline (PBS) followed by $4 \%$ paraformaldehyde. The brains were extracted from the skulls, washed in PBS, and sliced on a vibratome into $40 \mu \mathrm{m}$ coronal sections. Free-floating sections were then stored in cryoprotectant at $-20^{\circ} \mathrm{C}$ until immunohistochemical processing. Coronal sections were rinsed in PBS, and then placed in $1 \%$ hydrogen peroxide in PBS to block endogenous peroxidase. Next, sections underwent antigen retrieval using citra buffer at $70^{\circ} \mathrm{C}$ for 30 min (Antigen Retrieval Citra, BioGenex). Sections were then blocked in $0.1 \%$ triton$\mathrm{X}$ in PBS with 5\% goat serum for 1 hour and were incubated at $+4^{\circ} \mathrm{C}$ overnight in primary polyclonal antibody to p-ERK1/2 (1:200; \#9101 Cell Signaling Technology, Danvers, MA). The sections were incubated in a secondary antibody (Dako EnVision Kit, Dako, Carpinteria, CA) for one hour at room temperature and immunoreactivity was detected using nickel enhanced diaminobenzene (Dako EnVision Kit) as a chromagen. The sections were counterstained using toludine blue, mounted on slides, and cover-slipped. According to vendor data, the antibody labels two bands on Western blots corresponding to p-ERK1 and p-ERK2 (44 and $42 \mathrm{kDa}$, respectively), does not cross-react with phosphorylated JNK or p38 MAP kinases or non-phosphorylated ERK1/2

(http://www.cellsignal.com/products/9101.html). We confirmed that the p-ERK1/2 antibody labels two bands at 42 and $44 \mathrm{kDa}$ from adult nucleus accumbens tissue (data not shown) using Western methods as previously described [51].

Immunoreactivity was visualized using an Olympus CX41 light microscope (Olympus America, Center Valley, PA). Images were acquired using a digital camera (Regita model, QImaging, Burnaby, BC) interfaced to a desktop computer (Dell, Round Rock, TX) with image analysis software (Bioquant Nova Advanced Image Analysis; R\&M Biometric, Nashville, TN). The microscope, camera, and software were background corrected and normalized to preset light levels to ensure fidelity of data acquisition.

Data for p-ERK1/2 IR were acquired from a minimum of 4 sections/brain region/animal and averaged to obtain a single value per subject. Coordinates of brain regions analyzed were as follows: nucleus accumbens and proximal brain regions $(+0.86$ to $1.34 \mathrm{~mm}$ anterior to bregma), amygdala and proximal brain regions ( -1.7 to $-1.34 \mathrm{~mm}$ posterior to bregma). PERK1/2 immunoreactivity (IR) was quantified as the number of immunopositive pixels calculated from a circumscribed field (e.g., brain region), divided by the area of the region, and expressed as pixels $/ \mathrm{mm}^{2}$. Due to variability that occurs across individual immunohistochemistry experiments, independent parallel vehicle control groups were run for each dose of ethanol $(0.5,1$, and $3 \mathrm{~g} / \mathrm{kg})$ and processed at the same time as each ethanol dose. Therefore, data were expressed and analyzed as a percent change from parallel controls. Immunohistochemical data were collected and analyzed by a researcher blind to treatment conditions. Basal differences in p-ERK1/2 IR were analyzed via t-test. Effects of alcohol (age $\times$ dose) were analyzed via independent two-way ANOVAs at each dose of alcohol followed by Holm-Sidak multiple comparison procedures where appropriate using commercially available software (SigmaStat v. 3.01).

\subsection{Blood Ethanol Concentration}

In order to ensure that potential ontogenetic differences in p-ERK1/2 were not due to differential ethanol levels, blood ethanol concentration (BEC) was assessed 30-min after acute ethanol injection at the time of perfusion. Approximately $20 \mu \mathrm{l}$ of heart blood was centrifuged to provide $5 \mu \mathrm{l}$ of plasma for determination of ethanol concentration using an AM1 Alcohol Analyzer (Analox Instruments, Lunenburg, MA). BAC data were analyzed by two-way ANOVA (age $\times$ dose) using commercially available software (SigmaStat v. 3.01). 


\subsection{Novel Object Recognition Test}

The novel object recognition (NOR) test was conducted in eight covered sound attenuated, lighted locomotor activity chambers $\left(30 \mathrm{~cm}^{2}\right.$, Med Associates, Georgia, VT). Two sets of 16 pulse-modulated infrared photobeams were located on opposite walls to record ambulatory movements in the X-Y (horizontal) plane. All software settings were the same for adult and adolescent mice. The chambers were computer-interfaced (Med Associates) for data sampling at 50-millisecond resolution. Adolescent mice (PND 42) and adult mice (PND 84) were habituated to saline injections, cart transport, and the chamber (30 minutes) for three days prior to the NOR test [45].

On the test day, mice were transported via cart from the colony room to a procedure room. Mice were placed in the empty chambers for a 10 minute habituation period. Three object interaction sessions (each 10 minutes in duration) were separated by 5 minute intervals. Ethanol $(1 \mathrm{~g} / \mathrm{kg}$ ) or saline was injected (IP) in adolescent and adult mice immediately before the first session (sample object exposure 1) to evaluate effects of ethanol on memory acquisition. During session 1 (sample object exposure 1), two identical objects (either two filter tips or two eraser tops) were placed in the back right and left corners of the chamber for the sample object exposure. During session 2 (sample object exposure 2), mice were reexposed to the same two sample objects (familiar objects). During session 3 (novel object test), one familiar object was replaced with a novel object (whichever object had previously not been used). Objects and side of novel object presentation were counterbalanced across subjects.

Proximity to novel and sample objects was evaluated post hoc using Med-Associates Zone Analysis software. Sample and test objects (micro filter and pencil eraser top) were placed in the center of square zones $(6.5 \times 6.5 \mathrm{~cm}$ or $4 \times 4$ photo beams) located in the two back corners of the test environment. Object exploration was defined as the time spent in the zone of interest (breaking beams around each object) and was then converted to percent time spent in close proximity to the novel object as an index of novel object preference. General parameters of locomotor activity including total horizontal distance $(\mathrm{cm})$, total number of zone entries, and stereotypy (repetitive beam breaks) were also collected. Behavioral data were analyzed statistically via two-way ANOVA using commercially available software (SigmaStat v. 3.01)

\section{Results}

\subsection{Basal p-ERK1/2 Immunoreactivity}

Basal levels of p-ERK1/2 IR were significantly higher in adolescent, as compared to adult, in the CeA, BLA, mPFC, and NAcbSH (Table 1). No statistically significant differences were observed in nucleus accumbens core, or dentate gyrus. Qualitative observation also indicated the highest densities of p-ERK1/2 IR in the mPFC and CeA with lower levels of immunostaining seen in the dentate gyrus, the NAcbC, NAcbSh, and BLA in both age groups.

\subsection{Blood Ethanol Concentration (BEC) after Acute Injection}

No differences were detected in BEC between adolescent and adult C57BL/6J mice 30-min following acute ethanol $(0.5,1$, or $3 \mathrm{~g} / \mathrm{kg}$, IP) injection (Table 2). This suggests that any agedependent effects of ethanol on p-ERK1/2 IR or behavioral performance are not related to differential pharmacokinetics. 


\subsection{Effect of Acute Ethanol on p-ERK1/2 Immunoreactivity}

3.3.1. Nucleus Accumbens-As shown in Table 3, acute ethanol $(0.5-3 \mathrm{~g} / \mathrm{kg}$, IP) did not alter p-ERK1/2 IR in the nucleus accumbens core or shell in adolescent or adult mice as compared to parallel saline control when examined 30-min post injection.

3.3.2. Basolateral Amygdala-Low doses of acute ethanol $(0.5$ or $1 \mathrm{~g} / \mathrm{kg})$ had no effect on p-ERK1/2 IR in the BLA 30-min after injection (Table 3). However, an age $\times$ ethanol dose ANOVA indicated a significant main effect of age $(\mathrm{F}(1,43)=5.8, \mathrm{p}=0.02)$ and ethanol $(\mathrm{F}(1,43)=14.2, \mathrm{p}=0.0005)$ after acute injection of the highest dose of ethanol $(3 \mathrm{~g} / \mathrm{kg})$. In addition there was a significant interaction between ethanol and age $(\mathrm{F}(1,43)=5.8, \mathrm{p}=0.02)$ indicating that effects of acute ethanol $(3 \mathrm{~g} / \mathrm{kg})$ depended on developmental stage. Post hoc comparisons showed that ethanol produced a significant increase in p-ERK1/2 in adolescent (Holm-Sidak test, $\mathrm{p}=0.02$ ) but not adult mice (Figure 1A). Representative photomicrographs illustrating the cytological pattern of p-ERK1/2 IR in the BLA are shown in Figure 1B. pERK1/2 IR appears more intense in the neuropil and cell bodies of the BLA of adolescent mice as compared to adults.

3.3.3. Central Amygdala-As shown in Table 3, low doses of ethanol $(0.5 \mathrm{or} 1 \mathrm{~g} / \mathrm{kg})$ had no effect on p-ERK1/2 IR in the CeA in either age group. However, the high dose of ethanol $(3 \mathrm{~g} / \mathrm{kg})$ significantly increased p-ERK1/2 IR in this brain region in both adolescent and adult mice as indicated by a significant main effect of ethanol $(F(1,43)=75.02, p<0.0001)$ with no statistical interaction between age and ethanol. Planned comparisons (t-test) showed that ethanol $(3 \mathrm{~g} / \mathrm{kg})$ increased p-ERK1/2 IR in the CeA of both adolescent and adult mice (Table 3).

3.3.4. Medial prefrontal cortex-Similarly, in the mPFC, low doses of acute ethanol $(0.5$ or $1 \mathrm{~g} / \mathrm{kg}$ ) had no effect on p-ERK1/2 IR (Table 3). However, the high dose of ethanol $(3 \mathrm{~g} / \mathrm{kg})$ increased $\mathrm{p}$-ERK1/2 IR in the mPFC in both adolescents and adults as indicated by a significant main effect of ethanol $(F(1,33)=11, p<0.01)$. No main effects of age or ethanol $\times$ age interactions were observed.

3.3.5. Dentate Gyrus-The lowest dose of ethanol $(0.5 \mathrm{~g} / \mathrm{kg})$ had no effect on p-ERK1/2 IR in the dentate gyrus in adolescent of adult mice (Table 3). In contrast, the $1 \mathrm{~g} / \mathrm{kg}$ dose of ethanol produced age-dependent effects, with a significant decrease in p-ERK1/2 IR observed in adolescent mice only. A two-way ANOVA showed main effects of ethanol ( $\mathrm{F}$ $(1,41)=10.135, \mathrm{p}=0.003)$ and age $(\mathrm{F}(1,41)=6.506, \mathrm{p}=0.015)$ and an age $\times$ ethanol interaction $(\mathrm{F}(1,41)=7.163, \mathrm{p}=0.011)$. Post hoc (Holm-Sidak) comparisons confirmed that ethanol $(1 \mathrm{~g} / \mathrm{kg})$ produced a significant decrease in p-ERK1/2 IR in adolescent $(\mathrm{p}<0.05)$ but not adult mice (Figure 2A). Representative photomicrographs, illustrating the cytological pattern of p-ERK1/2 IR in the dentate gyrus after ethanol $(1 \mathrm{~g} / \mathrm{kg})$ injection, are shown in Figure 2B.

The high dose of ethanol $(3 \mathrm{~g} / \mathrm{kg})$ decreased p-ERK1/2 IR in the dentate gyrus as indicated by a significant main effect of ethanol $(F(1,33)=11, p<0.01$; Table 3$)$. Post hoc comparisons showed that the main effect of ethanol was due to a significant reduction in both age groups (Holm-Sidak, $\mathrm{p}<0.05)$. However, there was no main effect of age or an ethanol $\times$ age interaction.

\subsection{Novel Object Recognition}

3.4.1. Sample object exposure (Sample 1 and 2)_Adolescent and adult mice showed similar object exploration time (sec) with the sample objects (Table 4). Further, acute ethanol $(1 \mathrm{~g} / \mathrm{kg})$ injection did not interfere with object exploration as confirmed by a 2 - 
way ANOVA that showed no effect of age or ethanol on object interaction time during both Sample sessions 1 and 2 (Table 4).

3.4.2. Novel Object Recognition (NOR) test-An age (adolescent or adult) $\times$ ethanol $(0$ or $1 \mathrm{~g} / \mathrm{kg})$ 2-way ANOVA identified a significant main effect of age $(\mathrm{F}(1,41)=7.1$, $\mathrm{p}=0.011)$ and ethanol $(\mathrm{F}(1,41)=24.7, \mathrm{p}<0.001)$ on percentage of novel object interaction time. In addition there was a significant interaction between ethanol and age $(F(1,41)=5.5$, $\mathrm{p}=0.02$ ) indicating that the effect of ethanol on novel object interaction time depended on age. Post hoc comparisons showed that ethanol produced a significant decrease in the percentage of time spent with the novel object (relative to total object exploration time) in adolescent (Holm-Sidak test, $\mathrm{p}=0.001$ ) but not adult mice (Figure 3). Ethanol had no effect on total object exploration time (sec) during the novel object test in either age group (Table 4); thus, data represent a shift in relative time with the novel object.

\subsubsection{Locomotor Activity during Sample Exposures and NOR Test}

Total Zone Entries: During sample object exposures (Sessions $1-2$ ) and NOR test (Session 3), there were no statistically significant effects of age or ethanol treatment on the number of total zone entries (Figure 4A-C).

Total distance traveled: During the first sample exposure (Sample 1), an age $\times$ ethanol 2way ANOVA identified a significant main effect of age $(F(1,44)=17.7, p<0.0001))$ and ethanol $(\mathrm{F}(1,44)=6.2, \mathrm{p}=0.0165))$ on total distance traveled (Figure 4D). There was no interaction between age and alcohol. Since adolescent mice are more sensitive to the locomotor activating effects of acute ethanol [19], adolescent locomotor response to ethanol was evaluated via a planned-comparison procedure (t-test). Results showed that alcohol increased total distance traveled in adolescent mice (Figure $4 \mathrm{D}, \mathrm{t}(22)=2.6, \mathrm{p}=0.015$ )). During the second sample exposure (Sample 2), there was also a significant main effect of age $((\mathrm{F} 1,44=6.2, \mathrm{p}=0.016)$ on total distance traveled; however, the effect of ethanol was no longer observed (Figure 4E). Finally, during the NOR test, there was no effect of age or ethanol on total distance traveled (Figure 4F).

During the NOR test, no differences were observed between age and treatment conditions on several other measures of general motor activity including total distance traveled, stereotypic counts and zone entries (Figure 4A-C). Lack of differences in these measures suggests that the age-related differences in novel object interaction were not due to differences in general locomotor activity.

\section{Discussion}

Neuroadaptations in cell signaling and gene transcription pathways mediate behavioral pathologies in drug and alcohol abuse [52, 53]. A growing body of evidence also suggests that developmentally regulated neurobiological changes may leave adolescents vulnerable to experimenting with alcohol and other drugs of abuse and to drug-induced neuroadaptations $[1,54,55]$. However, the extent to which acute ethanol produces differential effects on molecular cell signaling pathways in the adolescent versus adult brain is not well understood. The present study examined age- and dose-dependent effects of acute ethanol exposure on p-ERK1/2 IR in mesocorticolimbic brain regions and their association with performance on the hippocampal-dependent novel object recognition test. Overall, results of this study indicate that acute ethanol produces dose- and age-dependent changes in pERK1/2 IR in anatomically restricted areas that may mediate differential behavioral responses to ethanol in adolescent versus adult mice. Importantly, age-dependent effects of ethanol were unrelated to differential blood ethanol concentration after acute treatment. 


\subsection{Basal Differences in p-ERK1/2}

An initial finding of this study is that basal ERK1/2 activation (phosphorylation) differs between adolescent and adult mice in mesocorticolimbic brain regions. Drug naïve adolescent mice showed higher p-ERK1/2 IR in the CeA, BLA, NAcbSh, and mPFC as compared to adults. Differential ERK1/2 activity in these brain regions may reflect wellcharacterized age-dependent differences in behavior $[1,54]$. For instance, the BLA is known to mediate conditioned fear and anxiety [56] and the mPFC is important in assigning emotional value to cognitive experiences [57]. BLA afferents connect to the mPFC [58, 59] and contribute to high-level functions of the organism such as decision making [60] and goal-directed behavior [61], both of which undergo significant changes during adolescence [1]. Moreover, increased ERK1/2 activation in the NAcbSh and BLA is associated with heightened alcohol-seeking behavior [62], which is characteristic of adolescents [55]. Developmental differences in frontal cortical control, or limbic reward, systems may also underlie adolescent impulsivity $[63,64]$, which has been linked experimentally to the pathogenesis of alcohol [65] and drug [66] abuse. Future studies could examine ERK1/2 activity in these neural circuits as a potential mechanism of age-dependent differences in emotion, cognitive processing, and impulsivity-induced drug-seeking behavior to determine if observed differences in basal expression have functional significance.

\subsection{Age-Independent Changes in p-ERK1/2}

Results of this study show that acute ethanol ( $3 \mathrm{~g} / \mathrm{kg})$ alters ERK1/2 phosphorylation in subregions of C57BL/6J mouse brain in a manner that does not depend on age. For example, a relatively high dose of acute ethanol ( $3 \mathrm{~g} / \mathrm{kg})$ increased p-ERK1/2 IR in the CeA by approximately 4.6 -fold in adolescent mice with a similar 5-fold increase observed in adults at 30-min post injection. This result complements recent evidence showing that increased pERK1/2 expression in the CeA is associated with the acute anxiolytic effects of ethanol $(1 \mathrm{~g} /$ $\mathrm{kg}$ ) 1-hour after injection and immediately after testing on the elevated plus maze [24]. It is unclear, however, why the present study did not replicate the effect of ethanol $(1 \mathrm{~g} / \mathrm{kg})$ on ERK1/2 phosphorylation but time after ethanol injection and presence, or absence, of behavioral testing may account for the discrepancy. With that caveat, these complementary results suggest that acute ethanol increases ERK1/2 phosphorylation in the CeA in an ageindependent manner.

Age-independent effects of acute ethanol on ERK1/2 phosphorylation were also observed in the mPFC. Similar to the CeA, acute ethanol ( $3 \mathrm{~g} / \mathrm{kg}$ ) increased p-ERK1/2 IR in the $\mathrm{mPFC}$ of adolescent and adult mice with no effects observed at the lower ethanol doses. This result is in contrast with data showing reduced p-ERK1/2 levels in mouse whole cerebral cortex after a similar dose of acute ethanol $(3.5 \mathrm{~g} / \mathrm{kg})$ in rats at postnatal days 5 and 21 [30]. These contrasting effects of a similar dosage of ethanol may depend on rodent species (rat versus mouse) or may indicate that acute ethanol produces subregion-specific changes in ERK1/2 activity in the cortex. Further evaluation of the effects of ethanol on ERK1/2 signaling in the cortex may uncover additional anatomically restricted differences. Overall, similar ontogenetic effects of acute ethanol ( $3 \mathrm{~g} / \mathrm{kg})$ on ERK1/2 phosphorylation in the CeA and mPFC observed here suggest that age-dependent differences in mouse behavioral responses to ethanol sedation (i.e., [67]) may not be mediated by the ERK/MAPK pathway in these brain regions.

\subsection{Age-Dependent Changes in p-ERK1/2}

Results from this study also indicate that acute ethanol produces changes in ERK1/2 phosphorylation that differ as a function of age. Acute ethanol $(3 \mathrm{~g} / \mathrm{kg})$ increased p-ERK1/2 IR in the BLA of adolescent C57BL/6J mice by over 4-fold but had no effect in adult mice. Lower doses of ethanol had no effect on p-ERK1/2 IR in the BLA. As noted above, 
evidence has implicated both the lateral and basal nuclei of the amygdala in the plastic changes underlyingacquisition and retention of fear conditioning, a model of associative learning $[56,68,69]$. ERK1/2 is transiently activated in the amygdala after fear conditioning and pharmacological blockade of ERK1/2 activation in the amygdala impairs fear memory consolidation [36]. Differences in activation of ERK1/2 in the BLA may suggest that adolescents attend to an acute ethanol cue, or to environmental stimuli paired with ethanol, differently than their adult counterparts. With repeated ethanol exposure, differential ERK1/2 activation in the adolescent BLA has the potential to produce maladaptive changes in function of the extended amygdala, which could contribute to increased vulnerability to addiction [70]. Increased ERK1/2 signaling in the BLA could directly contribute to increased ethanol-seeking behavior [62] or alter emotional and memory processing [71, 72], which could have adverse effects on adolescent propensity to use drugs.

A significant finding from this study is that cells in the dentate gyrus of adolescent mice were more sensitive to ethanol-induced reductions in ERK1/2 phosphorylation. Acute ethanol $(1 \mathrm{~g} / \mathrm{kg})$ significantly decreased p-ERK1/2 IR in the dentate gyrus of adolescent mice by approximately $50 \%$ and produced no change in adults indicating an adolescentspecific effect of this low dose of ethanol. By contrast, the higher dose of acute ethanol ( $3 \mathrm{~g} /$ $\mathrm{kg}$ ) decreased p-ERK1/2 IR in the dentate gyrus of both adolescent and adult mice. This effect of the high dose is consistent with prior results showing that acute ethanol $(3.5 \mathrm{~g} / \mathrm{kg})$ decreased p-ERK1/2 levels in the adult rat hippocampus at sixty minutes post injection [30] although that study did not identify a specific hippocampal sub-region where changes occurred. Given the prominent role of hippocampal ERK1/2 in memory processes [32], it is plausible that the memory impairing effects of ethanol may involve disruptions in ERK1/2 signaling in this key brain region and may relate to differences that have been observed between these two age groups in ethanol-induced memory deficits [73]. Importantly, the age-dependent differences in hippocampal response to alcohol were not associated with differences in basal expression of p-ERK1/2.

When considering potential mechanism(s) by which ethanol might increase ERK1/2 phosphorylation, it is imperative to consider a prominent biochemical effect of alcohol, which is to increase both extracellular dopamine [85] and glutamate [86] in the nucleus accumbens. Increases in ERK1/2 phosphorylation in the striatum are the result of coordinated activation of dopamine D1-like and NMDA receptors [87]. Importantly, alcohol activates ERK1/2 in the nucleus accumbens via a dopamine D1-dependent mechanism [31] and evidence indicates that both dopamine [10, 23, 88, 89] and NMDA [23, 90] receptor processes are altered by adolescent alcohol exposure. Although changes in ERK1/2 were not observed in the nucleus accumbens in the present study, differential effects of alcohol on ERK1/2 phosphorylation in other brain regions may reflect underlying age-dependent differences in dopamine and/or glutamate neurotransmission. In this way, ERK1/2 signaling in specific brain regions, may represent a point of convergence of key neurotransmitter, cell signaling, and transcriptional process in the development and maintenance of addiction [91]. Our research has shown that systemic ERK1/2 inhibition produces biphasic effects on operant low-dose alcohol self-administration [92] and its activity in the nucleus accumbens may underlie long-term adaptations associated with relapse [62] in adults. However, the role of this critical cell signaling pathway in the mechanisms and consequences of adolescent alcohol use remains to be further explored.

\subsection{Age-dependent Effects of Acute Ethanol on Object Recognition Memory}

Since ethanol $(1 \mathrm{~g} / \mathrm{kg})$ produced an adolescent-specific reduction in p-ERK1/2 phosphorylation in the dentate gyrus by ethanol $(1 \mathrm{~g} / \mathrm{kg})$, we sought to determine if this neural response was associated with differential behavioral effects of alcohol. To address this goal, adolescent and adult performance on the hippocampal-dependent novel object 
recognition (NOR) test following acute ethanol $(1 \mathrm{~g} / \mathrm{kg})$. Object recognition memory refers to the ability to judge a previously encountered item as familiar, and depends on the integrity of the hippocampus [74]. In this test rodents tend to explore novel objects to a greater extent than familiar objects, which is characterized as novel object preference [45].

Untreated adolescent and adult mice exhibited novel object preference of approximately $65 \%$, which is consistent with recent evidence obtained with 9 week old C57BL/6J mice [75]. Administration of acute ethanol $(1 \mathrm{~g} / \mathrm{kg}$ ) prior to sample object exposure significantly reduced novel object preference to chance levels $(<50 \%)$ only in adolescent mice. By contrast, performance on the novel object test by adult mice was unaffected by pretreatment with ethanol. This finding in adult mice is consistent with prior results showing no effect of acute ethanol $(1.6 \mathrm{~g} / \mathrm{kg})$ on adult object recognition memory [42]. However, interpreting the effects of acute ethanol on memory acquisition by adolescent mice requires understanding of the potential effects of ethanol on object exploration during training. Evidence indicates that acute ethanol $(2.4 \mathrm{~g} / \mathrm{kg})$ administered prior to object training interfered with object exploration during training [42], which might alter the ability to distinguish between familiar and novel objects during the memory test. Our results also show that ethanol $(1 \mathrm{~g} / \mathrm{kg})$ pretreatment had no effect on object interaction time during training or on measures of motor behavior during the memory test. This suggests that the results are not influenced by direct effects of ethanol on object interaction or motor activity. Thus, these data show that adolescent-specific ethanol-induced reductions in ERK1/2 activity in the dentate gyrus are associated with impaired object recognition memory. It will be interesting to determine in future studies if adolescent mice are differentially sensitive to ethanol-induced changes in memory acquisition versus consolidation processes.

These data show for the first time that ethanol-induced disruption of performance on a memory test is associated with reduced ERK1/2 activity in the hippocampus. This finding agrees with much of the literature addressing ethanol's effects on memory in adolescents and adults (recently reviewed by [76]). For example, adolescent rodents show ethanol-induced memory deficits $[77,78]$ and are more sensitive to ethanol's memory-impairing effects than adults $[13,16,17,79-81]$. However, these results do not agree with one study that found adult rats to be more sensitive than adolescents to the effects of ethanol $(1.5 \mathrm{~g} / \mathrm{kg})$ pretreatment on spatial memory acquisition [82]. Accumulating data also indicate that ERK1/2 activity is required for hippocampal-dependent memory functions, such as the novel object recognition test [34-37, 43, 83]. For example, intracerebroventricular infusion of the ERK1/2 inhibitor U0126 prevents consolidation of recognition memory, and recognition memory is associated with increased p-ERK1/2 in the hippocampus [37]. The potential mechanistic regulation of ethanol-induced memory impairment in adolescent mice via decreased ERK1/2 activity in the hippocampus should be directly tested. Further studies evaluating ERK1/2 inhibition, or activation, directly in the hippocampus could help clarify the role of ERK1/2 signaling in ethanol-induced changes in adolescent learning and memory. Moreover, since ethanol $(30 \mathrm{mM})$ enhances inhibitory tonic current more in adolescent dentate gyrus slices as compared to adults [84], it is plausible that this GABAergic physiological effect is partly mediated by reduced excitatory transmission as indicated by ethanol-induced reduction in activation of the ERK/MAPK pathway.

At low doses, acute ethanol increases locomotor activity to a greater extent in adolescent DBA2/J mice as compared to adults [19]. Thus, it was of interest in the present study to compare locomotor response to acute ethanol $(1 \mathrm{~g} / \mathrm{kg})$ during the NOR sample exposures and novel object tests. Analysis of variance showed that adolescent mice exhibited increased locomotor activity (distance traveled) during the two sample object exposure sessions irrespective of treatment (vehicle or alcohol); thus, there was no statistical interaction between age and alcohol on locomotor activity. Furthermore, this age-dependent variation in 
locomotion appeared general and did not alter the number of zone entries around sample objects during training. This suggests that adolescent mice engaged in heightened motor activity that was independent of the test objects. Since adolescent mice may show increased motor response to alcohol, we conducted post-hoc planned comparisons of motor activity within age groups following acute alcohol injection. Results showed that adolescent mice exhibited an increased response to alcohol but only during the first sample exposure session, which corresponds with other data from our group showing rapid motor effects of acute ethanol in C57BL/6J mice [85]. Overall, these show that adolescent C57BL/6J mice exhibit increased locomotor response to acute alcohol $(1 \mathrm{~g} / \mathrm{kg})$ but also suggest that this response did not influence the results of the NOR test.

In conclusion, results of this study show that adolescent C57BL/6J mice are more sensitive to acute ethanol-induced changes in ERK1/2 phosphorylation in the BLA and dentate gurus than their adult counterparts. The differences in ERK1/2 activation observed between the two age groups may have behavioral implications for learning and memory. Adolescentspecific reduction in ERK1/2 phosphorylation in the dentate gyrus was associated with disruption of hippocampal-dependent object recognition memory performance. Increased sensitivity to changes in cell signaling systems such as the ERK/MAPK pathway during adolescence may allow for both immediate consequences, including those observed in the novel object recognition test, or more long-term changes that are initiated by the first exposure to ethanol. Indeed, repeated high-dose ethanol $(5 \mathrm{~g} / \mathrm{kg})$ injection [86] or vapor exposure producing blood alcohol levels greater than $200 \mathrm{mg} \%$ [87] during adolescence disrupts working memory performance in adult rats. It remains to be determined, however, if long-term behavioral pathologies associated with adolescent ethanol exposure are regulated by the ERK/MAPK cell signaling system and whether the changes observed in this study produce vulnerability for future development of alcohol abuse and alcoholism.

\section{Acknowledgments}

This research was funded by NIH grants AA016629, AA014983, and AA011605 to CWH.

\section{References}

1. Spear LP. The adolescent brain and age-related behavioral manifestations. Neurosci Biobehav Rev. 2000; 24:417-63. [PubMed: 10817843]

2. Wills TA, Vaccaro D, McNamara G. Novelty seeking, risk taking, and related constructs as predictors of adolescent substance use: an application of Cloninger's theory. J Subst Abuse. 1994; 6:1-20. [PubMed: 8081104]

3. Laviola G, Adriani W, Terranova ML, Gerra G. Psychobiological risk factors for vulnerability to psychostimulants in human adolescents and animal models. Neurosci Biobehav Rev. 1999; 23:9931010. [PubMed: 10580313]

4. Laviola G, Macri S, Morley-Fletcher S, Adriani W. Risk-taking behavior in adolescent mice: psychobiological determinants and early epigenetic influence. Neurosci Biobehav Rev. 2003; 27:19-31. [PubMed: 12732220]

5. Kelley AE, Schochet T, Landry CF. Risk taking and novelty seeking in adolescence: introduction to part I. Ann N Y Acad Sci. 2004; 1021:27-32. [PubMed: 15251871]

6. Johnston, LD.; O'Malley, PM.; Bachman, JG.; Schulenberg, JE. Monitoring the Future national survey results on drug use, 1975-2008: Volume I, Secondary school students. National Institute on Drug Abuse; Bethesda, MD: 2009. (NIH Publication No 09-7402)

7. Grant BF, Dawson DA. Age of onset of drug use and its association with DSM-IV drug abuse and dependence: results from the National Longitudinal Alcohol Epidemiologic Survey. J Subst Abuse. 1998; 10:163-73. [PubMed: 9854701] 
8. Schuckit MA, Smith TL. The relationships of a family history of alcohol dependence, a low level of response to alcohol and six domains of life functioning to the development of alcohol use disorders. J Stud Alcohol. 2000; 61:827-35. [PubMed: 11188488]

9. Schuckit MA. Low level of response to alcohol as a predictor of future alcoholism. Am J Psychiatry. 1994; 151:184-9. [PubMed: 8296886]

10. Maldonado-Devincci AM, Badanich KA, Kirstein CL. Alcohol during adolescence selectively alters immediate and long-term behavior and neurochemistry. Alcohol. 2010; 44:57-66. [PubMed: 20113874]

11. Doremus TL, Brunell SC, Rajendran P, Spear LP. Factors influencing elevated ethanol consumption in adolescent relative to adult rats. Alcohol Clin Exp Res. 2005; 29:1796-808. [PubMed: 16269909]

12. Doremus-Fitzwater TL, Spear LP. Developmental differences in acute ethanol withdrawal in adolescent and adult rats. Alcohol Clin Exp Res. 2007; 31:1516-27. [PubMed: 17760786]

13. Hefner K, Holmes A. An investigation of the behavioral actions of ethanol across adolescence in mice. Psychopharmacology (Berl). 2007; 191:311-22. [PubMed: 17206494]

14. Silveri MM, Spear LP. Decreased sensitivity to the hypnotic effects of ethanol early in ontogeny. Alcohol Clin Exp Res. 1998; 22:670-6. [PubMed: 9622449]

15. Varlinskaya EI, Spear LP. Acute effects of ethanol on social behavior of adolescent and adult rats: role of familiarity of the test situation. Alcohol Clin Exp Res. 2002; 26:1502-11. [PubMed: 12394283]

16. White AM, Truesdale MC, Bae JG, Ahmad S, Wilson WA, Best PJ, et al. Differential effects of ethanol on motor coordination in adolescent and adult rats. Pharmacol Biochem Behav. 2002; 73:673-7. [PubMed: 12151043]

17. Markwiese BJ, Acheson SK, Levin ED, Wilson WA, Swartzwelder HS. Differential effects of ethanol on memory in adolescent and adult rats. Alcohol Clin Exp Res. 1998; 22:416-21. [PubMed: 9581648]

18. Philpot RM, Badanich KA, Kirstein CL. Place conditioning: age-related changes in the rewarding and aversive effects of alcohol. Alcohol Clin Exp Res. 2003; 27:593-9. [PubMed: 12711921]

19. Stevenson RA, Besheer J, Hodge CW. Comparison of ethanol locomotor sensitization in adolescent and adult DBA/2J mice. Psychopharmacology (Berl). 2008; 197:361-70. [PubMed: 18157521]

20. Yttri EA, Burk JA, Hunt PS. Intermittent ethanol exposure in adolescent rats: dose-dependent impairments in trace conditioning. Alcohol Clin Exp Res. 2004; 28:1433-6. [PubMed: 15597074]

21. Insel TR, Miller LP, Gelhard RE. The ontogeny of excitatory amino acid receptors in rat forebrain--I. N-methyl-D-aspartate and quisqualate receptors. Neuroscience. 1990; 35:31-43. [PubMed: 1972786]

22. Tarazi FI, Baldessarini RJ. Comparative postnatal development of dopamine $D(1), D(2)$ and $D(4)$ receptors in rat forebrain. Int J Dev Neurosci. 2000; 18:29-37. [PubMed: 10708903]

23. Pascual M, Boix J, Felipo V, Guerri C. Repeated alcohol administration during adolescence causes changes in the mesolimbic dopaminergic and glutamatergic systems and promotes alcohol intake in the adult rat. J Neurochem. 2009; 108:920-31. [PubMed: 19077056]

24. Pandey SC, Zhang H, Ugale R, Prakash A, Xu T, Misra K. Effector immediate-early gene arc in the amygdala plays a critical role in alcoholism. J Neurosci. 2008; 28:2589-600. [PubMed: 18322102]

25. Qi M, Elion EA. MAP kinase pathways. J Cell Sci. 2005; 118:3569-72. [PubMed: 16105880]

26. Sanna PP, Simpson C, Lutjens R, Koob G. ERK regulation in chronic ethanol exposure and withdrawal. Brain Res. 2002; 948:186-91. [PubMed: 12383974]

27. Valjent E, Corvol JC, Pages C, Besson MJ, Maldonado R, Caboche J. Involvement of the extracellular signal-regulated kinase cascade for cocaine-rewarding properties. J Neurosci. 2000; 20:8701-9. [PubMed: 11102476]

28. Kalluri HS, Ticku MK. Ethanol-mediated inhibition of mitogen-activated protein kinase phosphorylation in mouse brain. Eur J Pharmacol. 2002; 439:53-8. [PubMed: 11937092] 
29. Bachtell RK, Tsivkovskaia NO, Ryabinin AE. Alcohol-induced c-Fos expression in the EdingerWestphal nucleus: pharmacological and signal transduction mechanisms. J Pharmacol Exp Ther. 2002; 302:516-24. [PubMed: 12130710]

30. Chandler LJ, Sutton G. Acute ethanol inhibits extracellular signal-regulated kinase, protein kinase $\mathrm{B}$, and adenosine $3^{\prime}: 5^{\prime}$-cyclic monophosphate response element binding protein activity in an ageand brain region-specific manner. Alcohol Clin Exp Res. 2005; 29:672-82. [PubMed: 15834234]

31. Ibba F, Vinci S, Spiga S, Peana AT, Assaretti AR, Spina L, et al. Ethanol-induced extracellular signal regulated kinase: role of dopamine D1 receptors. Alcoholism, clinical and experimental research. 2009; 33:858-67.

32. Sweatt JD. Mitogen-activated protein kinases in synaptic plasticity and memory. Curr Opin Neurobiol. 2004; 14:311-7. [PubMed: 15194111]

33. Monti PM, Miranda R Jr. Nixon K, Sher KJ, Swartzwelder HS, Tapert SF, et al. Adolescence: booze, brains, and behavior. Alcohol Clin Exp Res. 2005; 29:207-20. [PubMed: 15714044]

34. Runyan JD, Moore AN, Dash PK. A role for prefrontal cortex in memory storage for trace fear conditioning. J Neurosci. 2004; 24:1288-95. [PubMed: 14960599]

35. Blum S, Moore AN, Adams F, Dash PK. A mitogen-activated protein kinase cascade in the CA1/ CA2 subfield of the dorsal hippocampus is essential for long-term spatial memory. J Neurosci. 1999; 19:3535-44. [PubMed: 10212313]

36. Schafe GE, Atkins CM, Swank MW, Bauer EP, Sweatt JD, LeDoux JE. Activation of ERK/MAP kinase in the amygdala is required for memory consolidation of pavlovian fear conditioning. $\mathrm{J}$ Neurosci. 2000; 20:8177-87. [PubMed: 11050141]

37. Kelly A, Laroche S, Davis S. Activation of mitogen-activated protein kinase/extracellular signalregulated kinase in hippocampal circuitry is required for consolidation and reconsolidation of recognition memory. J Neurosci. 2003; 23:5354-60. [PubMed: 12832561]

38. Walz R, Roesler R, Quevedo J, Sant'Anna MK, Madruga M, Rodrigues C, et al. Time-dependent impairment of inhibitory avoidance retention in rats by posttraining infusion of a mitogenactivated protein kinase kinase inhibitor into cortical and limbic structures. Neurobiol Learn Mem. 2000; 73:11-20. [PubMed: 10686120]

39. Zhang HT, Zhao Y, Huang Y, Dorairaj NR, Chandler LJ, O'Donnell JM. Inhibition of the phosphodiesterase 4 (PDE4) enzyme reverses memory deficits produced by infusion of the MEK inhibitor U0126 into the CA1 subregion of the rat hippocampus. Neuropsychopharmacology. 2004; 29:1432-9. [PubMed: 15114341]

40. Ryback RS. The continuum and specificity of the effects of alcohol on memory. A review. Q J Stud Alcohol. 1971; 32:995-1016. [PubMed: 4944697]

41. Ryback RS. Alcohol amnesia. JAMA. 1970; 212:1524. [PubMed: 5467553]

42. Ryabinin AE, Miller MN, Durrant S. Effects of acute alcohol administration on object recognition learning in C57BL/6J mice. Pharmacol Biochem Behav. 2002; 71:307-12. [PubMed: 11812537]

43. Bozon B, Kelly A, Josselyn SA, Silva AJ, Davis S, Laroche S. MAPK, CREB and zif268 are all required for the consolidation of recognition memory. Philos Trans R Soc Lond B Biol Sci. 2003; 358:805-14. [PubMed: 12740127]

44. Swartzwelder HS, Wilson WA, Tayyeb MI. Differential sensitivity of NMDA receptor-mediated synaptic potentials to ethanol in immature versus mature hippocampus. Alcohol Clin Exp Res. 1995; 19:320-3. [PubMed: 7625564]

45. Bevins RA, Besheer J. Object recognition in rats and mice: a one-trial non-matching-to-sample learning task to study 'recognition memory'. Nat Protoc. 2006; 1:1306-11. [PubMed: 17406415]

46. Orr PT, Lewis MC, Frick KM. Dorsal hippocampal progesterone infusions enhance object recognition in young female mice. Pharmacol Biochem Behav. 2009; 93:177-82. [PubMed: 19477194]

47. Baker KB, Kim JJ. Effects of stress and hippocampal NMDA receptor antagonism on recognition memory in rats. Learn Mem. 2002; 9:58-65. [PubMed: 11992016]

48. Silvers JM, Harrod SB, Mactutus CF, Booze RM. Automation of the novel object recognition task for use in adolescent rats. J Neurosci Methods. 2007; 166:99-103. [PubMed: 17719091]

49. Rutten K, Reneerkens OA, Hamers H, Sik A, McGregor IS, Prickaerts J, et al. Automated scoring of novel object recognition in rats. J Neurosci Methods. 2008; 171:72-7. [PubMed: 18372047] 
50. Wexler DB, Moore-Ede MC. Resynchronization of circadian sleep-wake and temperature cycles in the squirrel monkey following phase shifts of the environmental light-dark cycle. Aviat Space Environ Med. 1986; 57:1144-9. [PubMed: 3800813]

51. Wilkie MB, Besheer J, Kelley SP, Kumar S, O'Buckley TK, Morrow AL, et al. Acute ethanol administration rapidly increases phosphorylation of conventional protein kinase $\mathrm{C}$ in specific mammalian brain regions in vivo. Alcohol Clin Exp Res. 2007; 31:1259-67. [PubMed: 17511744]

52. Newton PM, Messing RO. Intracellular signaling pathways that regulate behavioral responses to ethanol. Pharmacol Ther. 2006; 109:227-37. [PubMed: 16102840]

53. Pandey SC. The gene transcription factor cyclic AMP-responsive element binding protein: role in positive and negative affective states of alcohol addiction. Pharmacol Ther. 2004; 104:47-58. [PubMed: 15500908]

54. Crews F, He J, Hodge C. Adolescent cortical development: a critical period of vulnerability for addiction. Pharmacol Biochem Behav. 2007; 86:189-99. [PubMed: 17222895]

55. Spear LP. The adolescent brain and the college drinker: biological basis of propensity to use and misuse alcohol. J Stud Alcohol Suppl. 2002:71-81. [PubMed: 12022731]

56. LeDoux JE. Emotion circuits in the brain. Annu Rev Neurosci. 2000; 23:155-84. [PubMed: 10845062]

57. Vogt BA, Finch DM, Olson CR. Functional heterogeneity in cingulate cortex: the anterior executive and posterior evaluative regions. Cereb Cortex. 1992; 2:435-43. [PubMed: 1477524]

58. Vogt BA, Pandya DN. Cingulate cortex of the rhesus monkey: II. Cortical afferents. J Comp Neurol. 1987; 262:271-89. [PubMed: 3624555]

59. Amaral DG, Insausti R. Retrograde transport of D- $[3 \mathrm{H}]$-aspartate injected into the monkey amygdaloid complex. Exp Brain Res. 1992; 88:375-88. [PubMed: 1374347]

60. Bechara A, Damasio H, Damasio AR, Lee GP. Different contributions of the human amygdala and ventromedial prefrontal cortex to decision-making. J Neurosci. 1999; 19:5473-81. [PubMed: 10377356]

61. Schoenbaum G, Chiba AA, Gallagher M. Changes in functional connectivity in orbitofrontal cortex and basolateral amygdala during learning and reversal training. J Neurosci. 2000; 20:5179_ 89. [PubMed: 10864975]

62. Schroeder JP, Spanos M, Stevenson JR, Besheer J, Salling M, Hodge CW. Cue-induced reinstatement of alcohol-seeking behavior is associated with increased ERK1/2 phosphorylation in specific limbic brain regions: blockade by the mGluR5 antagonist MPEP. Neuropharmacology. 2008; 55:546-54. [PubMed: 18619984]

63. Adriani W, Laviola G. Windows of vulnerability to psychopathology and therapeutic strategy in the adolescent rodent model. Behav Pharmacol. 2004; 15:341-52. [PubMed: 15343057]

64. Chambers RA, Potenza MN. Neurodevelopment, impulsivity, and adolescent gambling. J Gambl Stud. 2003; 19:53-84. [PubMed: 12635540]

65. Chen AC, Porjesz B, Rangaswamy M, Kamarajan C, Tang Y, Jones KA, et al. Reduced frontal lobe activity in subjects with high impulsivity and alcoholism. Alcohol Clin Exp Res. 2007; 31:156-65. [PubMed: 17207114]

66. Adriani W, Laviola G. Elevated levels of impulsivity and reduced place conditioning with damphetamine: two behavioral features of adolescence in mice. Behav Neurosci. 2003; 117:695703. [PubMed: 12931955]

67. Linsenbardt DN, Moore EM, Gross CD, Goldfarb KJ, Blackman LC, Boehm SL 2nd. Sensitivity and tolerance to the hypnotic and ataxic effects of ethanol in adolescent and adult C57BL/6J and DBA/2J mice. Alcohol Clin Exp Res. 2009; 33:464-76. [PubMed: 19120054]

68. Maren S. Long-term potentiation in the amygdala: a mechanism for emotional learning and memory. Trends Neurosci. 1999; 22:561-7. [PubMed: 10542437]

69. Fendt M, Fanselow MS. The neuroanatomical and neurochemical basis of conditioned fear. Neurosci Biobehav Rev. 1999; 23:743-60. [PubMed: 10392663]

70. Koob GF. The role of the striatopallidal and extended amygdala systems in drug addiction. Ann N Y Acad Sci. 1999; 877:445-60. [PubMed: 10415664]

71. Adams JP, Sweatt JD. Molecular psychology: roles for the ERK MAP kinase cascade in memory. Annu Rev Pharmacol Toxicol. 2002; 42:135-63. [PubMed: 11807168] 
72. Selcher JC, Weeber EJ, Varga AW, Sweatt JD, Swank M. Protein kinase signal transduction cascades in mammalian associative conditioning. Neuroscientist. 2002; 8:122-31. [PubMed: 11954557]

73. White AM, Swartzwelder HS. Hippocampal function during adolescence: a unique target of ethanol effects. Ann N Y Acad Sci. 2004; 1021:206-20. [PubMed: 15251891]

74. Squire LR, Wixted JT, Clark RE. Recognition memory and the medial temporal lobe: a new perspective. Nat Rev Neurosci. 2007; 8:872-83. [PubMed: 17948032]

75. Goodman T, Trouche S, Massou I, Verret L, Zerwas M, Roullet P, et al. Young hippocampal neurons are critical for recent and remote spatial memory in adult mice. Neuroscience.

76. Chin VS, Van Skike CE, Matthews DB. Effects of ethanol on hippocampal function during adolescence: a look at the past and thoughts on the future. Alcohol. 2010; 44:3-14. [PubMed: 20113870]

77. Popovic M, Caballero-Bleda M, Puelles L, Guerri C. Multiple binge alcohol consumption during rat adolescence increases anxiety but does not impair retention in the passive avoidance task. Neurosci Lett. 2004; 357:79-82. [PubMed: 15036579]

78. Silvers JM, Tokunaga S, Mittleman G, Matthews DB. Chronic intermittent injections of high-dose ethanol during adolescence produce metabolic, hypnotic, and cognitive tolerance in rats. Alcohol Clin Exp Res. 2003; 27:1606-12. [PubMed: 14574231]

79. Acheson SK, Stein RM, Swartzwelder HS. Impairment of semantic and figural memory by acute ethanol: age-dependent effects. Alcohol Clin Exp Res. 1998; 22:1437-42. [PubMed: 9802525]

80. Tapert SF, Schweinsburg AD, Barlett VC, Brown SA, Frank LR, Brown GG, et al. Blood oxygen level dependent response and spatial working memory in adolescents with alcohol use disorders. Alcohol Clin Exp Res. 2004; 28:1577-86. [PubMed: 15597092]

81. Brown SA, Tapert SF, Granholm E, Delis DC. Neurocognitive functioning of adolescents: effects of protracted alcohol use. Alcohol Clin Exp Res. 2000; 24:164-71. [PubMed: 10698367]

82. Rajendran P, Spear LP. The effects of ethanol on spatial and nonspatial memory in adolescent and adult rats studied using an appetitive paradigm. Ann N Y Acad Sci. 2004; 1021:441-4. [PubMed: 15251925]

83. Atkins CM, Selcher JC, Petraitis JJ, Trzaskos JM, Sweatt JD. The MAPK cascade is required for mammalian associative learning. Nat Neurosci. 1998; 1:602-9. [PubMed: 10196568]

84. Fleming RL, Wilson WA, Swartzwelder HS. Magnitude and ethanol sensitivity of tonic GABAA receptor-mediated inhibition in dentate gyrus changes from adolescence to adulthood. J Neurophysiol. 2007; 97:3806-11. [PubMed: 17376852]

85. Hodge CW, Mehmert KK, Kelley SP, McMahon T, Haywood A, Olive MF, et al. Supersensitivity to allosteric $\mathrm{GABA}(\mathrm{A})$ receptor modulators and alcohol in mice lacking PKCepsilon. Nat Neurosci. 1999; 2:997-1002. [PubMed: 10526339]

86. White AM, Ghia AJ, Levin ED, Swartzwelder HS. Binge pattern ethanol exposure in adolescent and adult rats: differential impact on subsequent responsiveness to ethanol. Alcohol Clin Exp Res. 2000; 24:1251-6. [PubMed: 10968665]

87. Schulteis G, Archer C, Tapert SF, Frank LR. Intermittent binge alcohol exposure during the periadolescent period induces spatial working memory deficits in young adult rats. Alcohol. 2008; 42:459-67. [PubMed: 18760715] 


\section{Research Highlights}

- Increased p-ERK1/2 IR in adolescent mouse brain regions as compared to adults

- Adolescent mice are more sensitive to ethanol-induced changes in ERK activation

- Greater sensitivity to ethanol disruption of object memory in adolescent mice 



Figure 1. Age-dependent effect of acute ethanol $(3 \mathrm{~g} / \mathrm{kg})$ on p-ERK1/2 IR in the basolateral amygdala (BLA) of adolescent mice

(A) Acute ethanol (3 g/kg) produced a greater than four-fold increase in p-ERK1/2 IR in the BLA of adolescent mice as compared to parallel age-matched saline controls (A, left). The same dose of ethanol had no effect on p-ERK1/2 IR in the BLA of adult mice (A, right). Data represent mean \pm SEM p-ERK1/2 IR and are plotted as percent change relative to mean value of saline control within each age group. * - indicates significantly different from saline control (Holm-Sidak, $\mathrm{p}<0.05$ ). (B) Representative images of $\mathrm{p}$-ERK1/2 IR in the BLA from saline and $\mathrm{EtOH}$ injected mice. Images were taken at 20X magnification 
A
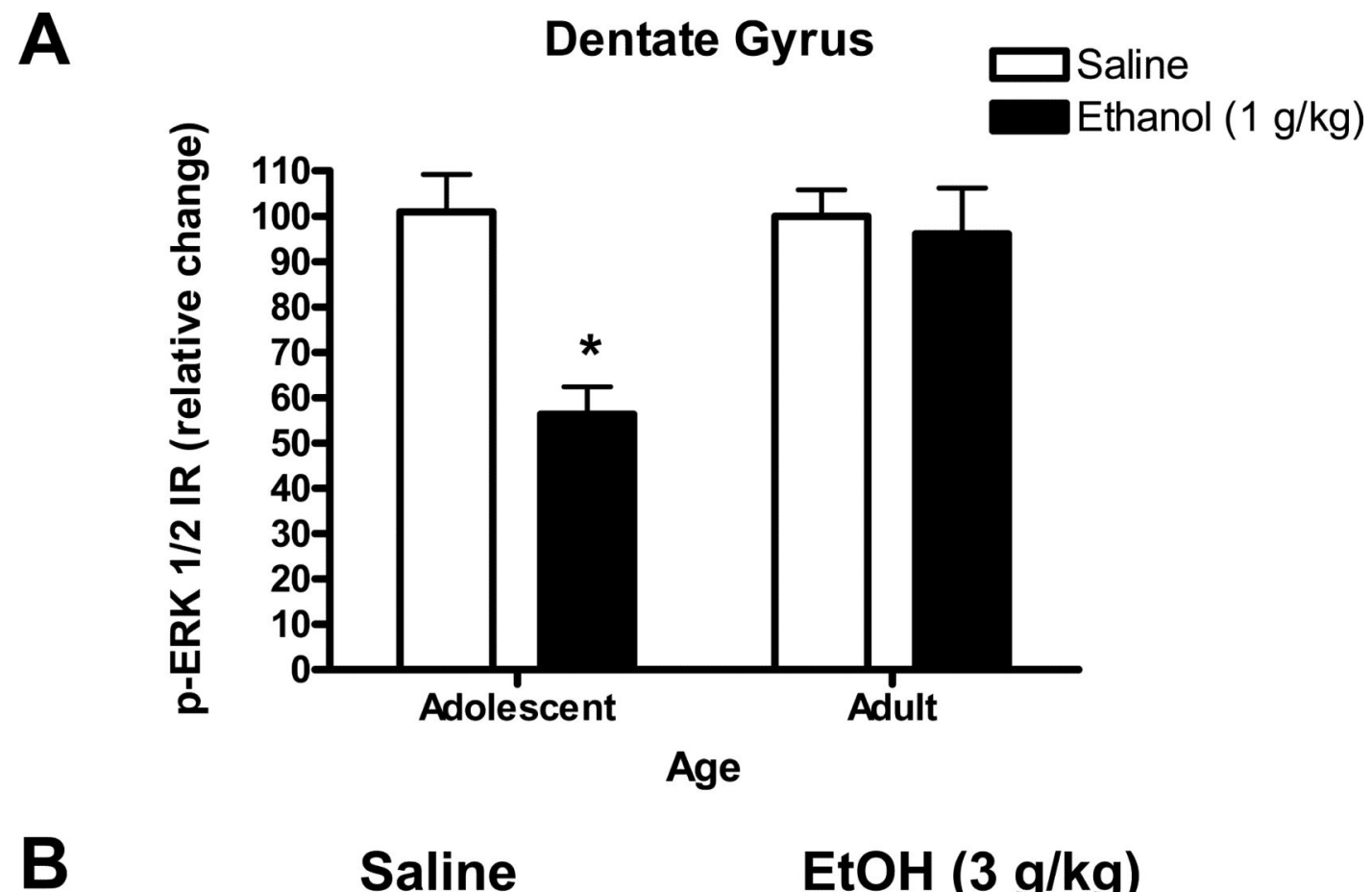

Saline

$\mathrm{EtOH}(3 \mathrm{~g} / \mathrm{kg})$



Figure 2. Age-dependent effect of acute ethanol $(1 \mathrm{~g} / \mathrm{kg})$ on $\mathrm{p}-\mathrm{ERK} 1 / 2 \mathrm{IR}$ in the dentate gyrus (A) Acute injection of ethanol $(1 \mathrm{~g} / \mathrm{kg})$ decreased p-ERK1/2 IR in the dentate gyrus of adolescent mice as compared to age-matched saline controls (A, left) but had no effect on adult mice (A, right). Data represent mean \pm SEM p-ERK1/2 IR plotted as a relative change (\%) compared to parallel saline controls. * - indicates significantly different from saline within age group, (Holm-Sidak, p<0.05). (B) Representative images of p-ERK1/2 IR in the dentate gyrus from saline and ethanol injected mice taken at 20X magnification. 


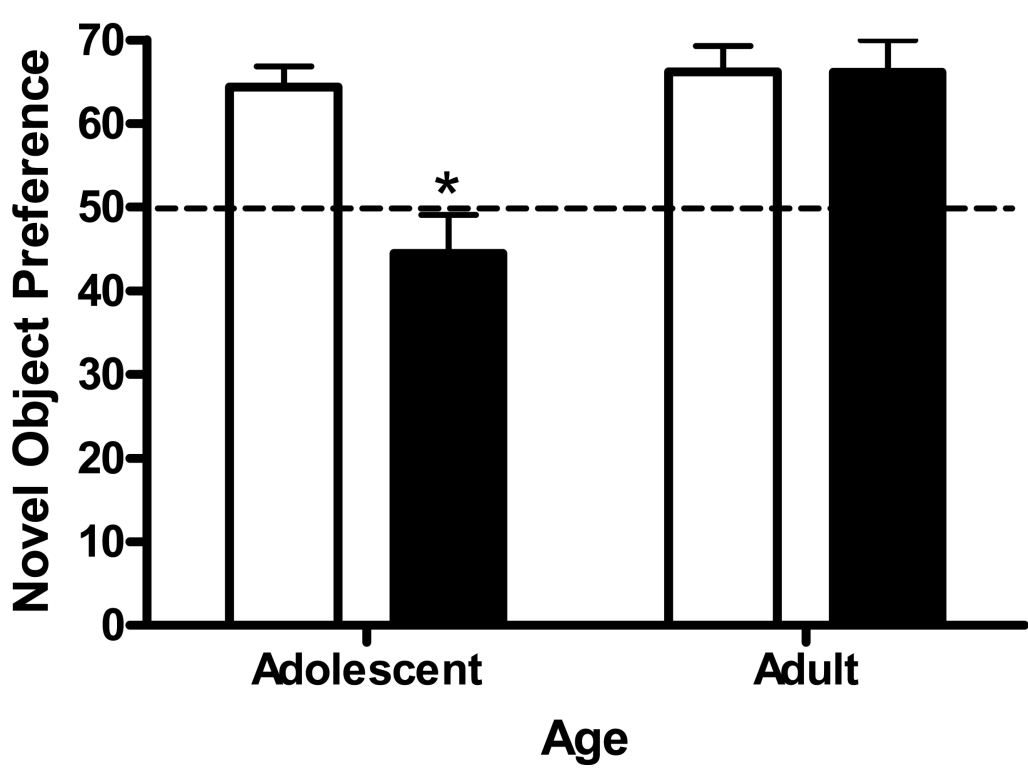

Figure 3. Age-dependent effect of acute ethanol $(1 \mathrm{~g} / \mathrm{kg})$ on adolescent and adult performance in the novel object recognition test

Adolescent mice injected with acute ethanol $(1 \mathrm{~g} / \mathrm{kg})$ interacted with the novel object significantly less than vehicle treated controls. No statistically significant effect of ethanol was observed in adult mice. Data represent mean \pm SEM $(n=12$ per condition) percentage of time interacting with the novel object (relative to total object interaction time). * - indicates significantly different from saline within age group, $(\mathrm{p}<0.05)$. 
Sample 1
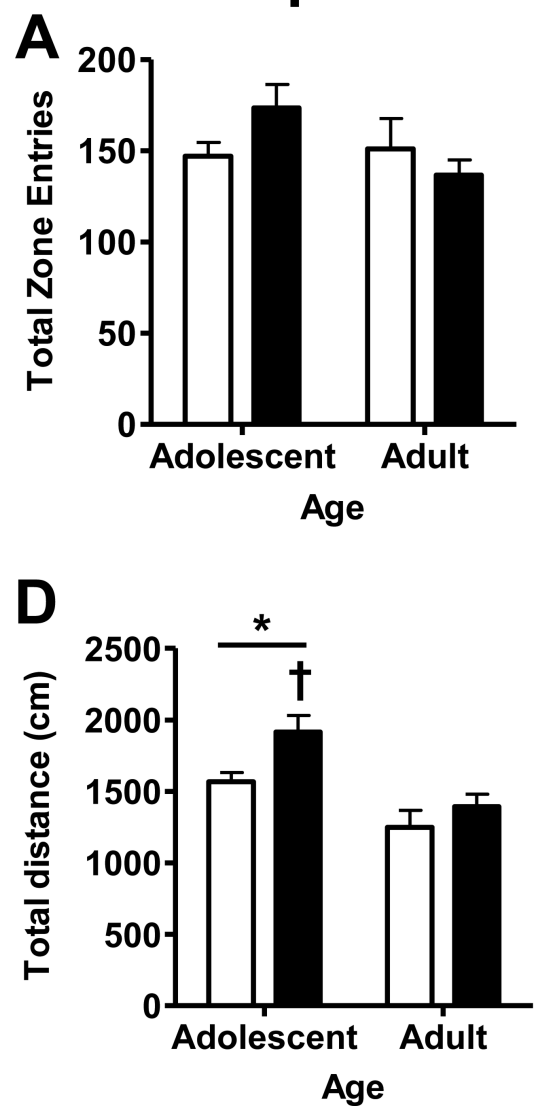

Sample 2
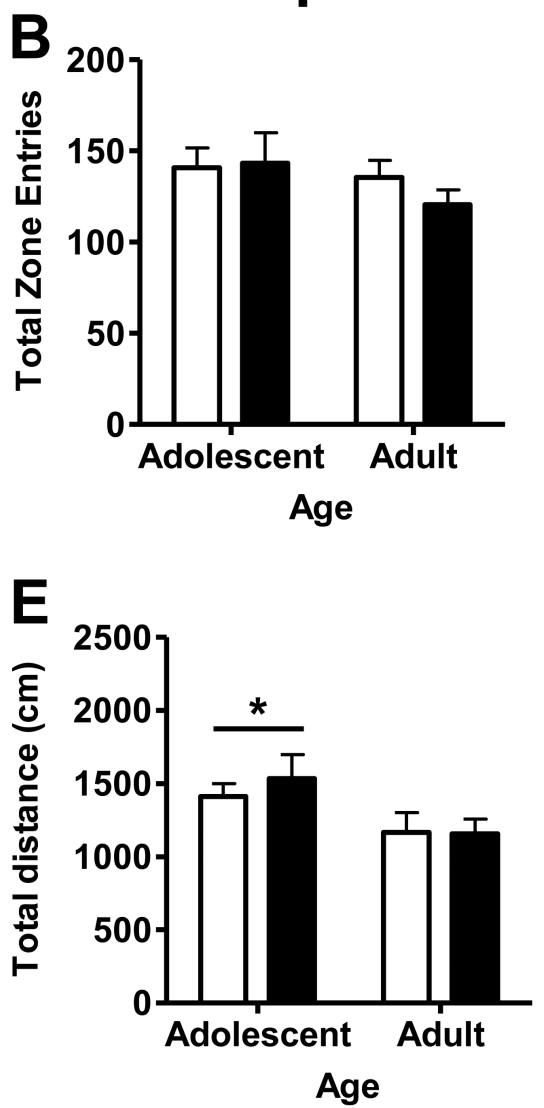

Novel Object Test


Figure 4. Measures of locomotor activity in ethanol $(1 \mathrm{~g} / \mathrm{kg})$ treated adolescent and adult mice during the novel object test

(A-C) No differences were observed in total number of zone entries (area proximal to objects) during Sample 1, 2, or Novel Object Test sessions. (D-E) Adolescent mice exhibited an overall increase motor activity as compared to adult mice (* - ANOVA main effect of age) during the two Sample (1 and 2) sessions. (D) In addition, adolescent mice showed a significant increase in total distance traveled $(\mathrm{cm})$ after ethanol administration during Sample 1 exposure as compared to saline control ( $\dagger, \mathrm{p}<0.05$; t-test). (F) No age- or ethanol-dependent differences in locomotor activity were observed during the Novel Object Test. Data represent mean \pm SEM ( $n=12$ per condition). 


\section{Table 1}

\section{Basal levels of adolescent and adult p-ERK1/2 immunoreactivity}

Basal p-ERK1/2 IR values (raw) \pm SEM derived from adolescent $(n=32)$ and adult $(n=30)$ mice in specified brain regions. * - indicates significantly different from adult, $\mathrm{p} \leq 0.05$, $\mathrm{t}$-test.

\begin{tabular}{|c|c|c|}
\hline Age & Brain regions & Basal p-ERK1/2 IR \\
\hline \multirow[t]{8}{*}{ Adolescent } & Amygdala & \\
\hline & Central & $6407.97 \pm 543.86^{*}$ \\
\hline & Basolateral & $3789.617 \pm 499.93^{*}$ \\
\hline & N. Accumbens & \\
\hline & Core & $3449.11 \pm 143.14$ \\
\hline & Shell & $3158.85 \pm 276.18^{*}$ \\
\hline & Medial Prefrontal Cortex & $8182.463 \pm 415.36^{*}$ \\
\hline & Dentate Gyrus & $12.25 \pm 0.62$ \\
\hline \multirow[t]{8}{*}{ Adult } & Amygdala & \\
\hline & Central & $3412.35 \pm 170.16$ \\
\hline & Basolateral & $2654.15 \pm 110.17$ \\
\hline & N. Accumbens & \\
\hline & Core & $3314.35 \pm 519.97$ \\
\hline & Shell & $2558.13 \pm 108.33$ \\
\hline & Medial Prefrontal Cortex & $6541.98 \pm 413.93$ \\
\hline & Dentate Gyrus & $12.1 \pm 0.56$ \\
\hline
\end{tabular}

Behav Brain Res. Author manuscript; available in PMC 2013 April 21. 
Table 2

Blood ethanol concentration (BAC) sampled 30 minutes after acute ethanol injection in adolescent and adult mice

No age-dependent differences were observed in BEC at any dose of ethanol tested. Data represent mean \pm SEM BEC (mg/dL) from $\mathrm{n}=12$ mice per condition.

\begin{tabular}{lccc}
\hline \multicolumn{3}{c}{ Alcohol Dose } \\
\hline Age & $\mathbf{0 . 5} / \mathbf{k g}$ & $\mathbf{1 . 0 g} / \mathbf{k g}$ & $\mathbf{3 . 0 g} / \mathbf{k g}$ \\
Adolescent & $43.2 \pm 1.31$ & $80.5 \pm 3.19$ & $288.6 \pm 3.86$ \\
Adult & $41.7 \pm 1.24$ & $81.1 \pm 3.49$ & $285.9 \pm 6.88$ \\
\hline
\end{tabular}




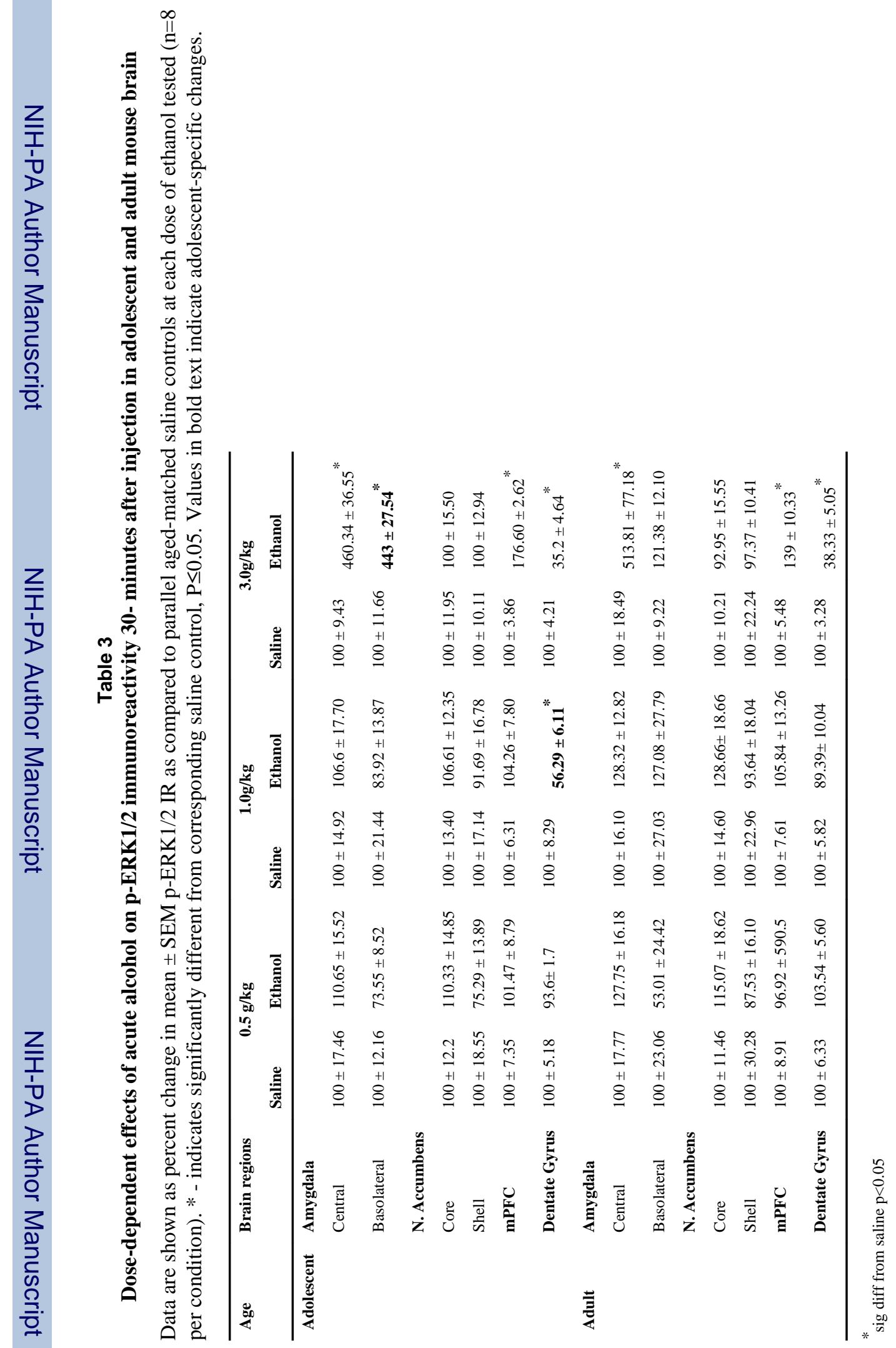

Behav Brain Res. Author manuscript; available in PMC 2013 April 21. 
Table 4

Total object exploration time (seconds) for adolescent and adult mice during sample object exposure and novel object test sessions

During each phase, adolescent and adult mice interacted with the filter and eraser top equally. Adolescents and adults also spent an equivalent amount of time exploring objects during each sample session and novel object exposure session. Data represent mean \pm SEM seconds ( $n=6$ per condition).

\begin{tabular}{lllcc}
\hline & & \multicolumn{3}{c}{ Session } \\
Age & Drug & Sample 1 & Sample 2 & Novel Object Test \\
\hline Adolescent & Saline & $356 \pm 24.3$ & $307 \pm 22.7$ & $201 \pm 18.2$ \\
& Alcohol & $316 \pm 16.6$ & $315 \pm 17.6$ & $207 \pm 31.9$ \\
\multirow{2}{*}{ Adult } & Saline & $329 \pm 22.9$ & $293 \pm 23.0$ & $173 \pm 19.2$ \\
& Alcohol & $309 \pm 18.9$ & $283 \pm 19.9$ & $244 \pm 33.9$ \\
\hline
\end{tabular}

